\title{
REFERRING TO A FRAME? SOME REFLECTIONS ON THE EUROPEAN CONTRACT LAW PROJECT
}

\begin{abstract}
Jan-Peter Trnka*
Summary: In 2005 the Joint Network on European Private Law was entrusted by the European Commission with drafting a Common Frame of Reference (CFR) for European contract law. In the Commission's own words, the CFR is to be 'a tool box for the Commission when preparing proposals, both for the existing acquis and for new instruments'. The Commission could not have emphasised more often that the CFR is not to become a new European Civil Code. Nevertheless, and perhaps paradoxically, the expected outcome of the Network's efforts is indeed a model law, ie a code, which is to be presented by the end of 2007.

This article focuses on two aspects of the overall harmonisation project. First, the constitutional setting for harmonising private law is highlighted. Are there limits to the internal market mandate? It would seem that the post-Maastricht challenge of setting such limits has not yet been resolved. The EC Treaty's post-Tobacco Advertising Article 95 does not provide unlimited competence to adopt a comprehensive European contract law. However, the lack of concrete criteria leaves much room for activity by the EC legislator. The article describes the criteria stipulated by the European Court of Justice, and also critically discusses the use of empirical data in this respect. In the second part, the meaning of the frame of reference and the first statements on the work in progress are examined. The new instrument will assume a concrete form very soon, and the paradox of drafting a CFR code while making 'no-code' claims demands attention. The Commission has defined what the Network should elaborate for the CFR as 'best solutions'. The article outlines the scope of the CFR and discusses the necessity of such an instrument, as well as the idea of finding 'best solutions'. In this respect, the idea of a regulatory competition scheme for European contract law is supported. Differences between national legal systems are the essential precondition for a learning process within the Community. At the same time, detecting inconsistencies within the existing acquis is a reasonable concern. One possible role of the CFR is to serve as a quality control instrument when drafting European legislation.
\end{abstract}

\footnotetext{
" Jan-Peter Trnka, University of Helsinki.
} 


\section{Introduction}

With the start of the millennium, a major European contract law project was launched. Backed by the Council and the European Parliament, the Commission has encouraged and supported numerous academic projects, getting stakeholders from various branches of the legal community and government experts into the game. ${ }^{1}$ In its three communications on European contract law, released in 2001, 2003 and 2004, the Commission inquired as to what the real needs in this field were. In response, there was more than one voice in the more enthusiastic early days of the project calling for a 'European Civil Code'. ${ }^{2}$ However, the stakes have changed: today we are striving for a Common Frame of Reference (CFR), and the Commission could not have emphasised more often that the CFR is not to become a new European Civil Code. Rather, it should provide 'a tool box for the Commission when preparing proposals, both for the existing acquis and for new instruments'. ${ }^{3}$ Nevertheless, and perhaps paradoxically, the expected outcome of the research network's efforts is indeed a model law, ie a code, which is to be presented by the end of $2007 .{ }^{4}$

However, the CFR is not the only possible outcome of the contract law project, whose envisaged objectives also include increased coherence and quality for the acquis and the elaboration of both EU-wide standard terms and conditions and an 'optional instrument'. ${ }^{5}$ Given the sheer breadth and complexity of the overall project, it would be impossible to try and comment on every single objective. This article's focus is, therefore, limited to discussion of the CFR. Nevertheless, two fundamental issues connected to the idea of harmonisation will be illuminated in this context. Following a short introduction to the project in general, the question of competences and the interplay of the supranational and Member State spheres is highlighted, while the project's search for 'best solutions'

\footnotetext{
1 For a summary of the latest developments, see H Beale, 'The European Commission's Common Frame of Reference Project: A progress report' (2006) ERCL 303.

2 Representatively, O Lando, 'Does the European Union need a Civil Code?' (2003) Recht der Internationalen Wirtschaft 1. Lando advocates an even wider view of a Global Commercial Code in (2004) Recht der Internationalen Wirtschaft 161.

3 Commission (EC), 'European Contract Law and the revision of the acquis: The way forward' (Communication) COM (2004) 651 final, 11 October 2004, Annex I (Possible structure of the CFR).

4 Christian von Bar, chairman of the Study Group on a European Civil Code, confirmed this at a hearing of the European Parliament's Committee on Legal Affairs on 21 November 2006: 'Wir werden den Verfassungsorganen der EU und der Öffentlichkeit in wenig mehr als einem Jahr einen Text vorlegen, der sich der Darstellungsform - ich betone: der Darstellungsform - eines kommentierten und annotierten Modellgesetzes bedient. Aber natürlich ist das kein Europäisches Zivilgesetzbuch. Es ist lediglich ein Stilmittel ....'.

5 See 2004 Communication (n 3).
} 
is discussed critically. It would seem that the post-Maastricht challenge of establishing limits to the internal market competence has not yet been resolved. Despite the need for action concerning contract law on various law-building sites and welcome contributions to the political project from academia, the overall effort to further invade the Member State sphere on such grounds seems undesirable.

\section{The evolution of European contract law}

\section{First steps towards common contract law rules}

When the European Economic Community was founded in 1957, the architects of the common market were primarily concerned with opening cross-border trade and increasing economic growth. All this began to change at the end of the 1970s, when the Member States recognised the need to develop a more comprehensive social policy at the European level. At this time, the Member States expressed their desire for European Community institutions to become involved in questions like public health and consumer protection. In the field of contract law, this recognition has led primarily to the gradual emergence of European consumer protection law. ${ }^{6}$ Sector-specific measures have included legislation on issues such as liability for defective products, doorstep selling, or consumer credit arrangements. ${ }^{7}$

But social policies and globalisation trends not only triggered activity by European legislators on the national and supranational levels; they also fostered numerous international and private academic efforts to establish uniform rules for contractual relations. As such, the Rome Convention on law applicable to contractual obligations, the UN Convention on the international sale of goods (CISG), and the UNIDROIT principles of international commercial contracts represent milestones on the way towards common contract law rules. ${ }^{8}$ Also, many academic working groups have become well established on the legislative scene since the 1980 s. $^{9}$

6 Concerning the origins and evolution of consumer law, see G Howells and T Wilhelmsson, EC Consumer Law (Ashgate/Dartmouth, Aldershot and Brookfield 1997).

7 Council Directive (EEC) 85/374 on the approximation of the laws, regulations and administrative provisions of the Member States concerning liability for defective products [1985] OJ L210/29; Council Directive (EEC) 85/577 to protect the consumer in respect of contracts negotiated away from business premises [1985] OJ L372/31; Council Directive (EEC) 87/102 for the approximation of the laws, regulations and administrative provisions of the Member States concerning consumer credit [1986] OJ L42/48.

8 An excellent collection of important texts on European private law, comprising the UN Sales Convention and the UNIDROIT principles, is O Radley-Gardner, H Beale, R Zimmermann and R Schulze, Fundamental Texts on European Private Law (Hart Publishing, Oxford and Portland 2003).

9 For a more comprehensive account, see eg B Lurger, Grundfragen der Vereinheitlichung des Vertragsrechts in der Europäischen Union (Springer, Wien/New York 2002) 11-21. 
It is no surprise, therefore, that leading members of the Commission on European Contract Law, led by Ole Lando; the Study Group on a European Civil Code, chaired by Christian von Bar; the Acquis Group, led by Hans Schulte-Nölke and Gianmaria Ajani; and the Common Core Group, centred around Ugo Mattei and Mauro Bussani, are today involved in the Joint Network on European Private Law (the CoPECL network), which is drafting the CFR. ${ }^{10}$

This revival of legislative activity at the European level accompanied the Single European Act of 1986, with its project of completing the formation of the internal market by the end of 1992. Among other measures, the current Articles 14 and 95 EC were introduced when the Treaty was revised. With the establishment of a single market, the European Community has begun to make an impact on commercial and consumer law in particular, and a multitude of directives have begun covering core areas of contract law. Community legislation based on the new Article 95 EC (formerly Article 100a EC) has started to govern such significant areas of contractual relations as the definition of unfair terms in consumer contracts, distance-selling arrangements, the sale of consumer goods, or e-commerce. ${ }^{11}$ Taking the comprehensive jurisdiction of the European Court of Justice (ECJ) into account, scholars are beginning to speak of 'European contract law in a factual sense' within the acquis communautaire. ${ }^{12}$

However, the internal market project is still under way in Europe, even fifteen years after the target date for its establishment in 1992. The Community legislator's sector-specific approach has not yet created an equal playing field for the various actors, while international conventions and commercial practices further complicate the search for coherence. The provisions of European secondary law have been characterised as

\footnotetext{
10 To name but a few of the most important research groups on the development of a common European contract law. For further information, see the official website of the Joint Network on European Private Law $(\mathrm{CoPECL}=$ Common Principles of European Contract Law) <http://www.copecl.org> accessed 30 May 2007.

11 Council Directive (EEC) 93/13 on unfair terms in consumer contracts [1993] OJ L95/29; Council Directive (EC) $97 / 7$ on the protection of consumers in respect of distance contracts [1997] OJ L144/19; Council Directive (EC) 1999/44 on certain aspects of the sale of consumer goods and associated guarantees [1999] OJ L171/12; Council Directive (EC) $2000 / 31$ on certain legal aspects of information society services, in particular electronic commerce, in the Internal Market (Directive on electronic commerce) [2000] OJ L178/1.

12 U Magnus, 'Europäisches Vertragsrecht und materielles Einheitsrecht - künftige Symbiose oder störende Konkurrenz?' in H Mansel, T Pfeiffer, H Kronke, C Kohler, R Hausmann (eds) Festschrift für Erik Jayme (Sellier, München 2004) 1307. The quantum of secondary legislation has finally led to the emergence of a separate legal discipline, ie European private law (Gemeinschaftsprivatrecht). Many textbooks have already been published in new and revised editions, eg B Heiderhoff, Gemeinschaftsprivatrecht ( $2^{\text {nd }}$ edn Sellier, München 2007).
} 
'islands in a broad sea of Member State law'. ${ }^{13}$ Thus many scholars argue that the diversity of national contract regimes remains an obstacle to intra-European cross-border trade, and that stronger action is needed. ${ }^{14}$ Nevertheless, national legal orders represent functioning legal systems, and so many other scholars have called for careful consideration before rushing into harmonisation projects. ${ }^{15}$

\section{Genesis of the European contract law project}

The idea of European contract law appeared on the European political agenda as a new initiative against fragmentation. The European Parliament had already called for a European code of private law in two Resolutions from 1989 and $1994 .{ }^{16}$ However, the contract law project in its present form may be said to have been launched only with the 'Tampere milestones', ie the conclusions of the European Council in Tampere in 1999, including a commitment to establish 'a genuine European area of justice' and, in particular, 'greater convergence in civil law'. ${ }^{17}$

In 2001 the Commission finally got active and adopted its Communication on European contract law, aimed at gathering information on whether there was a need for EU action in this area. ${ }^{18}$ Not only did the Commission enter the arena after being silent for so long; it also surprisingly challenged its own sector-specific, vertical approach to harmonisation, opening the debate on more far-reaching action: 'The European Commission is interested at this stage in gathering information on the need for farther-reaching EC action in the area of contract law, in particular to the extent that the case-by-case approach might not be able to solve all the problems which might arise'. ${ }^{19}$ In this regard, the options for future EC activity explicitly named were not limited to review and improvement of the acquis, but also included the development of common contract law principles and the adoption of comprehensive legislation. ${ }^{20}$

13 R Schulze, 'European Private Law and Existing EC Law' (2005) European Review of Private Law 3.

14 Representatively, U Drobnig, 'A Subsidiary Plea: A European Contract Law for IntraEuropean Border-Crossing Contracts' in S Grundmann and J Stuyck (eds), An Academic Green Paper on European Contract Law (Kluwer, The Hague 2002) 343.

15 One representative voice is the recently established Study Group on Social Justice in European Private Law. See their manifesto in 'Social Justice in European Contract Law: A manifesto' (2004) European Law Journal 653.

16 EC OJ 1989 C158/400 and EC OJ 1994 C205/518.

17 Tampere European Council 15 and 16 October 1999, Presidency Conclusions.

18 Commission (EC), 'On European contract law' (Communication) COM (2001) 398 final, 11 July 2001.

19 Ibid, Executive Summary.

20 Ibid, point 4. Option I: No EC action; Option II: Development of common contract law principles leading to more convergence of national laws; Option III: Improve the quality of legislation already in place; Option IV: Adopt new comprehensive legislation at EC level. 
Responses to the Communication pointed to manifold obstacles that would result from the diversity of national contract law. The problem areas identified included the following in particular:

- $\quad$ inconsistencies in specific cases where several EC acts may be applicable, with conflicting results;

- $\quad$ undefined or too broadly defined abstract legal terms in directives, such as, for example, 'contract', 'damage' or 'equitable remuneration';

- the principle of minimum harmonisation, which was criticised for not achieving uniform solutions; and

- $\quad$ the failure of some directives to solve problems in practice..$^{21}$

The Commission was quick to reply, drafting an Action Plan at the beginning of 2003, in which it set out its conclusions in light of these responses, and launching a second round of discussion. ${ }^{22}$ The Commission took the opportunity to set aside the option of non-intervention by the EC legislator and simply relying on the competition of legal orders. ${ }^{23}$ Instead, it emphasised the need to promote work on three initiatives. Besides the development of EU-wide standard contract terms, the Commission also named the CFR and an 'optional instrument', a 28th legal order which could be chosen by the parties, as objectives of the project. ${ }^{24}$ The followup Communication, entitled 'European Contract Law and the revision of the acquis: The way forward' and released in late 2004, already featured concrete guidelines for work on the CFR. ${ }^{25}$

It is important to note that the European contract law project kept moving even following the rejection of the European Constitution by France and the Netherlands, and despite the overall perception that integration initiatives in Europe would cease. At the beginning of May 2005, the European Commission approved funding for a network of academics,

${ }_{21}$ See, in particular, the Commission's summary in Commission (EC), 'A more coherent contract - An action plan' (Communication) COM (2003) 68 final, 12 February 2001, point 3.

22 Ibid.

${ }^{23}$ In this respect, see the critical discussion of contradictions and possible political motives and intentions on the Commission's part by M Kenny, 'The 2004 Communication on European Contract Law: Those magnificent men in their unifying machines' (2005) EL Rev 724, 728-729.

24 For the purpose of this article, the scope of discussion is limited mainly to the CFR. Thus the large debate on the Standard Contract Terms and the optional instrument, an opt-in versus an opt-out model, and other connected problems is not further discussed. On the latter, see eg J Basedow, 'Ein optimales Europäisches Vertragsgesetz - opt-in, opt-out, wozu überhaupt?' (2004) Zeitschrift für Europäisches Privatrecht 1. For a general overview of EC activitities, see M Röttinger, 'Towards a European Code Napoléon/AGBG/BGB? Recent EC Activities for a European Contract Law (2006) European Law Journal 807.

252004 Communication (n 3). 
practitioners and government experts charged with drafting the CFR. ${ }^{26}$ At the end of November of that year, the Competitiveness Council expressed its full support for all the activities initiated by the Commission, as did the European Parliament shortly afterwards. ${ }^{27}$

However, even as it established a major contract law project, the Commission also cautiously signalled certain reservations regarding its scope. During consultations the Commission has discreetly backed off from its earlier broad approach to legislative activity, refocusing the project on improving the existing acquis and assisting the preparation of any future acquis. The original idea of a comprehensive code for Europe was abandoned relatively soon, due to a lack of support at the political and academic level. ${ }^{28}$ Even the idea of an 'optional instrument' seems to be disappearing from the agenda. The 2003 Action Plan and the followup 2004 Communication still listed this 'optional instrument' among the measures to be elaborated, and at least invited further discussion on the 'opportuneness of this instrument'. ${ }^{29}$ The brief comments on such opportuneness in the Commission's first annual progress report in 2005, however, do not demonstrate much enthusiasm for a model law of broader scope.$^{30}$ A narrower approach is also apparent from various statements made by Commission officials and a change in focus of the workshops held by groups involved in discussing the CFR's scope. ${ }^{31}$ Indeed, workshops on wider aspects of contract law were cancelled in 2006, while those that were held concentrated on consumer law and, therefore, the existing acquis. ${ }^{32}$

${ }^{26}$ Cf C von Bar and H Schulte-Nölke, 'Gemeinsamer Referenzrahmen für europäisches Schuld- und Sachenrecht' (2005) Zeitschrift für Rechtspolitik 165.

27 See Conclusions of the Competitiveness Council, 28-29 November 2005; European Parliament resolution on European contract law and the revision of the acquis: The way forward, 23 March 2006; European Parliament resolution on European contract law, 4 September 2006.

28 This was especially due to the stakeholders and institutional actors, particularly the European Parliament, who expressed unwillingness to support these ideas without having a significant say in the decisions. Note the explicit wording of the 2004 Communication (n 3): '[I]t is important to explain that it is [not] the Commission's intention to propose a "European civil code" which would harmonise contract laws of Member States' (point 2.3).

29 See 2004 Communication (n 3) point 2.3 and Annex II.

30 Commission (EC), 'First Annual Progress Report on European Contract Law and the Acquis Review' (Report) COM (2005) 456 final, 23 September 2005.

31 Eg Commissioner M Kyprianou's speech 'European Contract Law: Better Lawmaking to the Common Frame of Reference' at the UK Presidency Conference in London 26 September 2005, <http://ec.europa.eu/commission_barroso/kyprianou/speeches_en.htm> accessed 30 May 2007.

32 Cf S James at the hearing of the European Parliament's Committee on Legal Affairs on 21 November 2006, <http://www.europarl.europa.eu/hearings/2006_en.htm> accessed 30 May 2007. 
Against this background, the first issue to be highlighted is one which might explain many of the reservations concerning legislative activism, ${ }^{33}$ namely, the limits to contract law harmonisation imposed by the European Constitution in its present form, in particular by the competence provisions.

\section{Competences and their limitation}

The 2004 Communication expressly mentions Articles 65, 95 and $308 \mathrm{EC}$ as possible competence provisions with respect to private law codification. ${ }^{34}$ With regard to substantive contract law, however, only the latter two provisions could provide fruitful grounds. Article $65 \mathrm{EC}$ obviously does not offer the possibility of serving as a basis for competence in harmonising substantive law. ${ }^{35}$ It grants the EC legislator the competence to adopt measures concerning judicial cooperation in civil matters with cross-border implications and, insofar as is necessary, in order to ensure the proper functioning of the internal market. Nevertheless, these provisions of Article $65 \mathrm{EC}$ relate to harmonising conflict rules and civil procedure. Moreover, this article is found under Title IV of the EC Treaty, ie among policies relating to the free movement of persons ('Visas, asylum and other policies related to free movement of persons'). The focus on harmonising procedural rules and the limitation to the free movement of persons thus make it hard to interpret the provisions of this article as grounds for harmonising substantive law related to the sale of goods. ${ }^{36}$

On second glance, Article $308 \mathrm{EC}$ is also unlikely to serve as the basis for a comprehensive harmonisation of contract law. First of all, scholars have rightly argued that legislative action based on Article 308 EC would lack democratic legitimacy, since the current legislative procedure foresees neither the participation of the European Parliament nor substantial involvement by national parliaments. ${ }^{37}$ Moreover, its provisions could only serve as the legal basis for a Community measure where no other provisions of the Treaty would grant Community institutions the power necessary to adopt it. In this respect, the relevance of Article 308 EC has

\footnotetext{
33 Even the 2004 Communication (n 3) refers to a lack of response to the competence question: '[V]ery few contributors expressed their view on that issue.' (Annex II, point 6).

34 See the 2004 Communication (n 3) 21.

35 Some scholars do, however, believe that Art 65 EC, although not a legal basis for comprehensive legislative action, could nevertheless serve as a basis for harmonising substantive law on a small scale. For references, see eg M Ludwigs, 'Harmonisierung des Schuldvertragsrechts in Europa - Zur Reichweite der gemeinschaftsrechtlichen Zuständigkeit für eine Europäisierung des Privatrechts' (2006) Europarecht 370, 381.

36 Ludwigs (n 35); Lurger (n 9) 112-114.

37 Cf S Leible, 'Die Mitteilung der Kommission zum Europäischen Vertragsrecht - Startschuss für ein Europäisches Vertragsgesetzbuch?' (2001) Europäisches Wirtschafts- und Steuerrecht 471, 479; Ludwigs (n 35) 394-395.
} 
diminished since the Single European Act of 1986 introduced Article 95 EC as a special competence provision aimed at market integration. With regard to the contract law project, recourse to Article 308 EC could only be considered if a measure were to aim at creating a new kind of legal system separate from national systems, and if it could not be regarded as simply aiming to approximate the laws of Member States in terms of Article 95 EC. ${ }^{38}$ Given that a comprehensive codification of contract law has been removed from the agenda, and that the idea of approximating laws prevails in debates on European contract law, Article 95 EC provides a competence provision worth examining.

\section{The internal market mandate: open-ended or restricted competence in pursuit of market integration?}

The introduction of Article 95 EC into the Treaty (formerly Article 100a EEC) was the result of efforts to revive the internal market project in the 1980s. It gives the EC legislator the power to adopt measures for approximating laws whose object is the establishment and functioning of the internal market, based simply on a qualified majority decision in the Council. The competence provision additionally features a special characteristic providing for a strong role by the Community legislator in market integration. It is not sector-specific, but rather provides broad grounds for action in pursuit of the Community's objective of establishing 'an area without internal frontiers in which the free movement of goods, persons, services and capital is ensured in accordance with the provisions of this Treaty'. ${ }^{39}$ This also makes the provision specific with respect to its competence-delimiting principles, particularly those relating to the limited attribution of powers and subsidiarity. Many commentators raised the question of how to make the competence delimiting principles work in practice. ${ }^{40}$ In this respect, no help came from the ECJ, which seemed reluctant to express its position regarding the limits of the internal market mandate. It took more than a decade following the introduction of Article 95 EC before the Court intervened for the first time.

In its famous Tobacco Advertising judgment in 2000, the ECJ for the first time struck down a directive as lacking a legal basis. The Court annulled a directive that contained a total ban on tobacco advertising. ${ }^{41}$

\footnotetext{
38 For example, the creation of a new form of cooperative society permitted recourse to Art 308 EC. See Case 436/03 European Parliament $v$ Council [2006] ECR I-3733.

39 Article 14(2) EC.

40 For an excellent account of the issue, also with respect to the solutions in the Treaty on a Constitution for Europe, see S Weatherill, 'Better Competence Monitoring' (2005) EL Rev 23.

41 Directive(EC) 98/43 of the European Parliament and of the Council on the approximation of the laws, regulations and administrative provisions of the Member States relating to the advertising and sponsorship of tobacco products [1998] OJ L213/9.
} 
Besides dealing with the tricky question of whether the directive aimed at market harmonisation or public health, one of the Court's most important findings was that Article $95 \mathrm{EC}$ does not confer a general competence on the Community to regulate the internal market, and that a provision must be interpreted in light of the principle of conferral in Article 5 EC:

To construe that article [Article $95 \mathrm{EC}$ ] as meaning that it vests in the Community legislature a general power to regulate the internal market would not only be contrary to the express wording of the provisions cited above but would also be incompatible with the principle embodied in Article 3b of the EC Treaty (now Article 5 EC) that the powers of the Community are limited to those specifically conferred on it. ${ }^{42}$

However, even though the ECJ's decision made it clear that there are judicially policed limits to the Treaty's functionally broad competences, the limits of Article $95 \mathrm{EC}$ have not been redefined since the Tobacco Advertising ruling. Nor did the recent ruling on the follow-up tobacco advertising directive provide any new insights. ${ }^{43}$ Nevertheless, the Tobacco Advertising cases reveal much concerning the crux of the requirements which must be met before adopting measures pursuant to Article 95 EC. Naturally, such measures must, first of all, genuinely aim to improve conditions for the establishment and functioning of the internal market. ${ }^{44}$ Secondly, they have to aim at eliminating current obstacles to trade and preventing their future emergence through the diverse development of national laws or, alternatively, preventing an appreciable risk of distortion of competition. ${ }^{45}$

\section{Contract law: an obstacle to trade?}

But what does this mean in terms of divergent national contract laws? Do differences in contract laws create obstacles to trade? It has at least been made clear that obstacles to trade resulting from the varying development of national laws cannot be assumed simply by identifying disparities among national legal systems:

\footnotetext{
42 Case 376/98 Federal Republic of Germany $v$ European Parliament and Council [1999] ECR I-8419 para 83. The Court again refers explicitly to the "principle, that the powers of the Community are those specifically conferred on it' when arguing for case-by-case verification of an appreciable distortion of competition; see paras 107/108.

43 Case 380/03 Federal Republic of Germany $v$ European Parliament and Council [2006] ECR I- 11573.

44 Case 376/98 (n 42) para 84.

45 Cf Case 376/98 (n 42) paras 85/86 and 106/107.
} 
While a mere finding of disparities between national rules is not sufficient to justify having recourse to Article $95 \mathrm{EC}$, it is otherwise where there are differences between the laws, regulations or administrative provisions of the Member States which are such as to obstruct the fundamental freedoms and thus have a direct effect on the functioning of the internal market. ${ }^{46}$ (emphasis added)

However, what does the Court tell us about obstacles to trade here? One way of reading these lines would be to restrict recourse to Article 95 EC to situations where measures run contrary to Article $28 \mathrm{EC}$ and, as such, 'obstruct the fundamental freedoms'. In this respect, it is far from clear whether the provisions of national contract law could be subsumed under the requirements of Article $28 \mathrm{EC}$, and thus constitute obstacles to trade at all. The answer would have to be negative if contract law provisions were characterised as selling arrangements as per Keck. In Keck and Mithouard the ECJ decided that only rules relating to product requirements (shape, size, colour, etc) could be illegal, while those concerning selling arrangements (opening hours, staff training requirements, etc) could not be. Many scholars have thus tried to classify contract law rules or divide them into groups according to this differentiation. ${ }^{47}$ In this regard, some have argued for a classification of contract law provisions as selling arrangements. After all, contract law regimes do not provide rules concerning the consistency or packaging of products, and so can always be classified as selling arrangements. ${ }^{48}$ Therefore, since contract law provisions can be seen as selling arrangements, and thus not contrary to Article $28 \mathrm{EC}$, the assumption of obstacles to trade as per Article 95 EC seems impossible.

Yet reading such a restriction into the Court's words seems unconvincing. The formulation 'it is otherwise where' does not necessarily exclude the assumption of 'obstacles to trade' in other constellations. Moreover, the supposition that Article 28 EC would limit Article 95 EC is likewise not very convincing. On the contrary: is there not a need for positive harmonisation measures, or at least for discussion of such measures, when Article $28 \mathrm{EC}$ fails to ensure the free movement of goods, be it due to a justification of national measures pursuant to Article $30 \mathrm{EC}$, other 'mandatory requirements', or because 'selling arrangements' are involved ${ }^{49}$ Negative and positive harmonisation motives should not be artificially linked in this way. Also, Keck should be viewed more as a judg-

46 Case 380/03 (n 43) para 37; as for the old Directive, cf Case 376/98 (n 42) paras 84, 95.

47 For an overview of approaches, see O Langer, 'Das Kaufrecht auf dem Prüfstand der Warenverkehrsfreiheit des EG-Vertrages' (2001) RabelsZ 222.

48 In this regard, see eg Ludwigs (n 35).

49 Similarly, Ludwigs (n 35) 382. 
ment about Article $28 \mathrm{EC}$, and not about the internal market competence provision. ${ }^{50}$ However, this is not the place for extensive discussion of this issue. The point is only to show that contract law provisions might not be subsumed under 'obstacles to trade' in the sense of Article 95 EC. It is, therefore, interesting to examine which requirements would have to be fulfilled in order to assume 'distortions of competition', the second pillar of the internal market mandate.

\section{'Appreciable' distortion of competition - empirical studies as a last resort?}

In this respect, reference to Article $95 \mathrm{EC}$ would also be possible if divergent laws were to incontestably represent an appreciable risk of distortion of competition. ${ }^{51}$ It is here, again, that the Court fails to provide more concrete tools for scrutinising Community measures: which distortion is 'appreciable', and which is not? It is not surprising, therefore, that both the Community measures based on Article $95 \mathrm{EC}$ and the Court's rulings have met with strong criticism. ${ }^{52}$ Concerning non-mandatory rules, for example, one could generally argue against the assumption of an 'appreciable' distortion of competition, since the parties to a contract have an influence on its formation..$^{53}$ Accordingly, only mandatory contract law rules could be subject to harmonisation, and thus consumer protection rules in particular. ${ }^{54}$ However, even if one were to focus only on mandatory contract law, no feasible criteria would emerge in the face of different national legal solutions, values and cultures.

Empirical studies seem to have a considerable importance in this respect. Hitherto the Commission has also relied on surveys conducted with the relevant parties, eg consumers and business, to justify its actions. In its argumentation, the Commission often draws on Eurobarometer surveys, for example. However, this approach can also be criticised in many respects. One private project which offered exemplary critical insight was that conducted on behalf of a major English law firm, with Vogenauer and Weatherill acting as academic advisors. ${ }^{55}$ This law firm com-

\footnotetext{
50 Similarly, Lurger (n 9) 106.

51 Cf Case 376/98 (n 42) para 106.

52 As for the 2006 tobacco advertising ruling, see eg M Rauber, 'Das Tabakwerbeverbotsurteil des EuGH' (2007) Zeitschrift für Europarechtliche Studien 151.

53 In this vein, see the obiter in Case 339/89 Alsthom Atlantique v Sulzer [1991] ECR I-107 para 15. For more comprehensive accounts of this issue, see eg Langer (n 47) or Ludwigs (n 35).

54 Cf Article 5 of the Rome Convention on the law applicable to contractual obligations.

55 See their comments in S Vogenauer, S Weatherill, 'The European Community's competence for a comprehensive harmonisation of contract law - an empirical analysis' (2005) EL Rev 821.
} 
missioned a survey amongst 175 firms in eight Member States, seeking to include a mix of both larger and smaller economies and old and new Member States. The point of departure seemed to be a certain scepticism among the members of the law firm as to whether users of contract law, and businesses more specifically, really do find different legal systems to be an obstacle to trade which distorts competition. ${ }^{56}$

The project's findings give good reason for scepticism about survey results. It is important to mention here that the project rightly underscored the importance of empirical research and, in this respect, even supported some of the Commission's findings in a more comprehensive European survey from 2002. As such, the law firm's survey also revealed that businesses view the concept of harmonised contract law favourably, to a large degree. ${ }^{57}$ However, it also revealed the shortcoming of surveys and the difficulties encountered in drafting questions. For example, questions concerning mandatory rules for protecting consumers and other weaker parties or the possible negative consequences of introducing a European contract law were not included, so as to enable the drafting of a manageable questionnaire.$^{58}$ As for the law firm's project, there are no better concluding words than the authors' own:

Let us finally acknowledge that even if businesses unanimously wished to have a uniform contract law, this would not entail that it has to be given to them. If asked, they probably would also want to have zero taxes and the lowest possible standards of consumer protection. There may be valid reasons, in the interests of consumers and society as a whole (in this case: societies as a whole), not to go ahead with further harmonisation. ${ }^{59}$

In a European Union of 27 or (soon) even more members, it will never be possible to draft an all-embracing questionnaire, or involve a big enough number of representatives from all of the Member States and sub-national actors so as to reach a fully comprehensive and satisfactory survey. Moreover, the results of such surveys will always be open to interpretation. Some examples of such interpretation will be given when discussing the CFR below.

In any case, it must be concluded that Article 95 EC does not provide an unlimited competence to adopt a comprehensive European contract law. While its scope has been far from clear hitherto, the constraints introduced by the ECJ and reasons of democratic legitimacy demand

\footnotetext{
56 Ibid, references on p 830.

57 Ibid 835.

58 Ibid 829-830.

59 Ibid 837.
} 
that extensive (mis)use of the internal market provision in the pursuit of contract law harmonisation must be considered carefully. In particular, the vague definition of 'obstacles to trade' and 'distortions of competition' means that the reasoning behind measures at the European level remains within the discretion of the EC legislator. The lack of more concrete criteria calls for increased transparency on the part of the European legislator when proposing and drafting legislation.

\section{Who is to decide? - the everlasting debate on subsidiarity}

It was precisely such Community empowerments as Article 95 EC which led to growing resistance among Member States, after the Community's sphere of activity was expanded through the Single European Act. ${ }^{60}$ As a result, the current Article $5 \mathrm{EC}$ was introduced into the Maastricht Treaty as a safeguard against extensive supranational (mis)use of competences. With the inclusion of the guiding principles in the Treaty, 'conferral' was to underscore the Member States' role as the Herren der Verträge, while 'subsidiarity' was to guarantee them a strong say as to the level of decision-making, at least as far as the Member States themselves and sub-national actors were concerned. ${ }^{61}$ As depicted above, however, the non-sector-specific Article $95 \mathrm{EC}$ seems to speak a language of its own. Likewise, the subsidiarity principle as embodied in today's Article 5(2) EC provides more a political tool than a legal safeguard against the extensive exercise of competence.

The principle of subsidiarity was introduced into the Maastricht Treaty in 1992, to counter-balance an alleged centralisation of powers and thus delimit the Community's competences. It has certainly captured the attention of an increasing number of legal scholars and policymakers since then. ${ }^{62}$ However, while now unquestionably playing a key role in the legislative process, the idea of creating an ex post judicial

60 In addition, Art $95 \mathrm{EC}$ suddenly confronted Member States with the qualified majority voting system.

${ }^{61}$ For deeper reflection on the competence delimitation debate and additional references, see J-P Trnka, 'Subsidiarity: Competence Control or Political Masquerade?' in N Neuwahl and S Haack (eds), Unresolved Issues of the Constitution for Europe-Rethinking the Crisis (Les Éditions Thémis, Montreal 2007) 239.

62 In this context, the European Subsidiarity Conference 'Europe begins at home', held in Austria on 18/19 April 2006, and the cooperative efforts between European institutions and national parliaments within the framework of the Conference of European Affairs Committees (COSAC) may be mentioned. Recent scholarly publications include S Albin, 'Das Subsidiaritätsprinzip in der EU - Anspruch und Rechtswirklichkeit' (2006) Neue Zeitschrift für Verwaltungsrecht 629; I Cooper, 'The Watchdogs of Subsidiarity: National Parliaments and the Logic of Arguing in the EU' (2006) Journal of Common Market Studies 281; and C Ritzer, M Ruttloff and K Linhart, 'How to sharpen a Dull Sword - The Principle of Subsidiarity and its Control' (September 2006) German Law Journal <http://www.germanlawjournal.com> accessed 30 May 2007. 
safeguard has failed so far. ${ }^{63}$ When the ECJ was asked to decide on the requirements and scope of the subsidiarity principle, it became obvious that the Court would be required to make demanding assessments of an essentially political nature, ie as to whether Member States' measures would be sufficient, or if Community action would be preferable. It is not surprising, therefore, that the ECJ has not referred to the subsidiarity principle very frequently, and has avoided an elaboration of the principle's material content. So far the ECJ has never annulled a measure for infringement of the subsidiarity principle.

With respect to the European contract law project, however, it is not even necessary to delve deeper into the debate on this principle. Nor is it necessary to recall discussions as to whether Article $95 \mathrm{EC}$ represents an exclusive competence of the Community and, therefore, cannot be affected by the subsidiarity principle. The idea of approximation as such already limits the effectiveness of the principle, since it would, in fact, be difficult for a single Member State to prove that it could approximate laws better than the Community legislator: 'As the scope of that protection has immediate effects on trade, and, accordingly, on intra-Community trade, it is clear that, given the scale and effects of the proposed action, the objective in question could be better achieved by the Community'. ${ }^{64}$ As such, subsidiarity does not provide fertile ground for delimiting the internal market mandate.

We shall now return to the European contract law project and its search for the best solutions for the entire European Union and, in this respect, to the CFR, the proclaimed lighthouse in the vast sea of European contract law.

\section{The Common Frame of Reference and the search for 'best solutions'}

CFR - three letters that might indicate the project's outcome: Confusion, Fragmentation and Restraint? Be that as it may, a tight time schedule has been set for the CFR project, and many actors have joined the game. A first draft is expected to be available already at the end of 2007 . In the second half of 2008 a White Paper, including the final draft CFR, should be published for further consultation with the general public before the final CFR is adopted by the end of 2009, ie the end of the Barosso Commission. ${ }^{65}$

The overall project is being led by the Commission's Directorate-General for Health and Consumer Protection (DG SANCO), but elaboration of

\footnotetext{
63 For a more comprehensive account of the subsidiarity principle, see Trnka (n 61).

64 Case 377/98 The Netherlands $v$ Parliament and Council [2001] ECR I-7079 para 32.

65 Cf C von Bar and H Schulte-Nölke (n 26).
} 
the first draft of the CFR was commissioned from the academic CoPECL network, which is to interact with two other groups in its efforts. ${ }^{66}$ On the one hand, there is a network of stakeholders, the 'CFR-net', bringing together stakeholder experts from business, consumer organisations and the legal profession, so as to ensure active participation by practitioners; on the other, a group of government experts from the Member States, who should provide input of national viewpoints into the project. The choice and involvement of these many actors have, of course, led to continual criticism of the CFR project and its efforts. For example, the initial role of DG SANCO was rightly questioned, since the contract law project has, to all intents and purposes, always been an internal market project affecting many areas besides consumer protection. To address this problem, an inter-service group within the Commission has since been established, whose aim is to ensure that the interests of other Commission services are also taken into account. ${ }^{67}$ Also, many of the CoPECL network's other members do not feel sufficiently involved in the drafting process. ${ }^{68}$ Despite these organisational problems, however, much work has already been done, and it is interesting to examine the first foreshadowed outcomes.

One is tempted to ask what exactly is this frame of reference supposed to be? Is it one of those massive frames with rich ornamentation, which shapes the identity of the entire composition? Or is it one of those thin, rudimentary ones, leaving all the space for a famous European work of modern art that aims to unite all the elements in their diversity? In fact, answering these questions should be easy - all the more so since the Commission outlined the CFR's possible function and structure in its 2004 Communication. ${ }^{69}$ In brief, the original aim was to improve the quality and coherence of both the existing acquis and future legal instruments in the area of contract law, while at the same time serving to simplify the acquis and provide clear definitions of legal terms and fundamental principles, as well as coherent model rules for contract law. ${ }^{70}$ The Communication even defined individual issues, dividing them into chapters, sections, numbers and letters. Yet the final outcome of the CFR project is still unknown. It is possible, therefore, only to sum up what factors might affect its ultimate output.

66 For a deeper account of the current range of actors, see Röttinger (n 24) 817-822.

67 Ibid 817.

68 Cf Beale (n 1); for a critical account from a government expert, see T Astola, 'Katsauksia ja pienempiä kirjoituksia' (2007) Lakimies 573.

692004 Communication (n 3) Annex I.

70 Cf 2004 Communication (n 3). 


\section{What the CFR will not be, and what it might be}

Confronted with the letters 'CFR', an American observer might think of the Code of Federal Regulations, ie a codification of permanent, general rules divided into 50 titles representing the broad areas subject to federal regulation. In Europe, however, CFR stands for Common Frame of Reference and, indeed, a European counterpart to the Code of Federal Regulations could never exist - certainly not a 'federal' instrument, and most likely not a 'code' or 'regulations', either. Why is that? Above all, the European Union is not a federation. Europe has decided for a 'constitutional Sonderweg'. ${ }^{71}$ Even though it comprises some 'federal' arrangements in its architecture, it is not a full-fledged federation. Its institutional arrangement, for example, is rather of a confederal nature, with the Council, and thus the Member States' representatives, having the last word in decision-making. Above all, a federal state would presuppose the existence of a European constitutional demos. ${ }^{72}$ However, the European model is based on the distinct peoples of its components. In Commissioner Grybauskaite's words: 'The EU is not a federation, it does not have a federal government and our integration is going differently'. ${ }^{73}$

Secondly, there is no striving for a European code. Already in its 2004 Communication, the Commission explicitly renounced the idea of an all-embracing code: 'It is important to explain that it is [not] the Commission's intention to propose a "European civil code" which would harmonise contract laws of Member States'. ${ }^{74}$ And the Council's conclusions to date have welcomed 'the Commission's repeated reassurance that it does not intend to propose a "European Civil Code" which would harmonise contract laws of Member States, and that Member States' differing legal traditions will be fully taken into account'. ${ }^{75}$ Thirdly, the (short-term) outcome will probably not be a regulation. A regulation in terms of Article 249 of the EC Treaty is an EU decision that directly binds all Member States and citizens all over the EU. It is directly applicable, which means that it need not be transposed into national law, but rather confers rights or imposes duties on Community citizens in the same way as national law. Of course, one could conceive of a contract law codifica-

\footnotetext{
71 JHH Weiler, 'In defence of the status quo: Europe's constitutional Sonderweg' in JHH Weiler and M Wind (eds) European Constitutionalism beyond the State (CUP, Cambridge 2003) 7.

72 Cf P Kirchhof, 'Europa auf dem Weg zu einer Verfassung?' in K Beckmann, J Dieringer and U Hufeld (eds) Eine Verfassung für Europa (2 ${ }^{\text {nd }}$ edn Mohr Siebeck, Tübingen 2005) 359, or Weiler (n 71).

73 Commissioner Grybauskaite in an interview with the EU Observer on 7 March 2007, concerning the harmonisation of taxes in Europe.

742004 Communication (n 3) para 2.3.

75 Conclusions of the Competitiveness Council, 28/29 November 2005, no 10.
} 
tion that would be adopted in the form of a regulation. This view was also confirmed by many commentators in their response to the Commission's Communications. ${ }^{76}$ However, even in recognising these commentators' preference for an 'opt-in' instrument taking the form of a regulation, the Commission 'considers at this stage that the CFR would be a non-binding instrument'. ${ }^{77} \mathrm{~A}$ CFR in the form of an EU regulation seems, therefore, rather unrealistic.

However, after this 'negative selection' of what the CFR will not be, it is interesting to consider what the CFR could or will be, particularly since adoption of the final CFR is already foreseen for $2009 .{ }^{78}$ Recent events have provided a picture of how the CFR project might culminate. In the exact words of the Commission, the CFR will be 'a tool box for the Commission when preparing proposals, both for the existing acquis and for new instruments'. ${ }^{79}$ While the author's dictionary of legal terminology does not feature 'tool box', the Oxford English Dictionary has fortunately helped him out. According to the latter, 'tool box' may be defined as a 'reservoir of instruments with which some operation is performed', or as a 'means of effecting something'. However, even when applying these definitions, there are at least two possible interpretations. The more narrow one would opt for an instrument with which an operation, or - in the European context - a legislative activity, is performed. The other would favour a reservoir of ideas as a means of effecting something, be it binding codes or model laws of whatever kind and scope. And this paradox is reflected in the proposals which have been arriving one after the other lately. Whole books could be filled just with the outlines of all these ideas. However, it is the CoPECL network which has been entrusted with elaborating the first draft of the CFR, and thus will have the first say; and its approach seems to differ from the low-profile, 'no-code' attitude of the Commission.

The academic working groups have focused on a broader understanding of the CFR, an option given to them by the Sixth Framework Programme, which supports independent research and thus allows results independent of the Commission's directive. ${ }^{80}$ The outcome of the

762004 Communication (n 3): 'As we have seen above, a great majority of respondents expressed its preference for an "opt in" instrument. If this approach is followed, there is significant support for a regulation' (point 3).

772004 Communication (n 3) para 2.1.3.

78 See Beale (n 1) for a summary of the work in progress.

792004 Communication (n 3) Annex I (Possible structure of the CFR).

80 The Sixth Framework Programme is the European Community Framework Programme for Research, Technological Development and Demonstration. It is a collection of EU-level actions for funding and promoting research. For further information, see $<$ http://ec.europa. eu/research/fp6> accessed 20 March 2007. 
academics' efforts will most probably resemble an updated version of the Principles of European Contract Law. ${ }^{81}$ Christian von Bar recently outlined this picture at a hearing of the European Parliament's Committee on Legal Affairs on 21 November 2006: 'In less than a year we will present to the constitutional institutions of the EU and the public a text which will be in the form [...] of a commentated and annotated model law'. ${ }^{82}$ To be politically correct, he added: '[N]aturally, it will not be a European Civil Code. This is solely a stylistic device. ${ }^{\circ 3}$

However, it is certainly too early to evaluate the CFR efforts, as they remain above all a work in progress. Nor does this article intend to delve into details and speculation. Nevertheless, the new instrument will assume a concrete form very soon, and the paradox of drafting a CFR code while making 'no-code' claims demands attention. In this respect, the Commission's latest statements on the CFR project may reveal some of its intentions for the way ahead. In its First Annual Progress Report on European Contract Law and Acquis Review from the end of 2005, the Commission reflected on the work undertaken to that date and outlined the main policy issues. ${ }^{84}$ Most recently, the Commission published a Green Paper on the Review of the Consumer Acquis, concluding the diagnostic phase of its review of the consumer acquis and summing up the Commission's initial findings. ${ }^{85}$ This document's title suggests that it only refers to the 'parallel project' of reviewing the acquis. The CFR is, however, supposed to be a tool box for the review procedure. Thus it is interesting to examine what the 'best solutions' are meant to be, and what attitude and intentions the Commission reveals in its latest Green Paper.

\section{The search for best solutions}

The Commission has defined what the research network is to elaborate for the Common Frame of Reference as 'best solutions'. ${ }^{86}$ For this purpose, the 2004 Communication gives guidelines about where to look for them: 'The research preparing the CFR will aim to identify best solutions, taking into account national contract laws [...], the EC acquis and

\footnotetext{
81 O Lando and H Beale (eds) Principles of European Contract Law. Parts I and II Combined and Revised (Kluwer, The Hague 2000); O Lando, E. Clive, A Prüm and R Zimmermann (eds) Principles of European Contract Law. Part III (Kluwer, The Hague 2003).

82 Free translation; see n 4 above for the original wording.

83 Ibid.

84 First Annual Progress Report (n 30).

85 Commission (EC) 'Green Paper on the Review of the Consumer Acquis' (Green Paper) COM (2006) 744 final, 8 February 2007. The Commission findings are the result of a comparative analysis of eight consumer law directives in 25 Member States, conducted by a research team led by H Schulte-Nölke.

862004 Communication (n 3) point 3.1.3.
} 
relevant international instruments [...]'. ${ }^{87}$ However, such a guideline does not help to define what a 'best solution' is supposed to be. One could, of course, argue that there will always be some solution in one of the Member States' legal systems that 'best' serves the purpose at hand. However, does this mean that 26 of the 27 Member States, not to mention international conventions, opt for 'bad solutions'? Hardly likely. Rather, it is a question of a whole 'package of solutions' representing the standard in the given domestic sphere, and depending on different cultures, values and other motives. So, how to define the 'best solution' among all these good choices? And who decides for whom the best solution is really 'best'?

Even before the start of the European contract law project, one of the central issues in academic discussion of the harmonisation of European contract law was whether or not it should be accomplished via legislative activity. ${ }^{88}$ Two schools of thought have generally dominated the debate. The positivist school favours the formal unification of European contract law 'from above', while others doubt whether the time has come for a Europe-wide codification of contract law. This latter school seeks to avoid the problems of static codification, advocating the development of a common private law 'from below' through an informal, 'creeping' process. ${ }^{89}$ Commentators have found various other names for these two options, be they ex ante versus ex post harmonisation, or 'top down' versus 'bottom up'. The reasons for following one or the other line are of a diverse ideological or pragmatic nature. As for the European way, a combination of both approaches - top down and bottom up - is today's reality. Some kind of middle way will have to be found in the future as well, in order to ensure diversity while promoting common goals. The question, then, is how much the European legislator should interfere in the national sphere?

When talking about harmonisation in terms of interference in the national sphere, however, the opening of national legal orders and the negative harmonisation approach should not go unmentioned. Back in 1985, the Commission's White Paper on completion of the internal market proposed a new approach to European regulation, including as its key elements the restriction of legislative harmonisation and the principle of 'mutual recognition' of rules and standards among the Member States, meaning that 'goods lawfully manufactured and marketed in one Member State must be allowed free entry into other Member States'.$^{90}$ This

\footnotetext{
87 Ibid.

88 See eg KP Berger, 'Harmonisation of European Contract Law, The Influence of Comparative Law' (2001) ICLQ 877.

89 For a representative opinion survey, see An Academic Green Paper on European Contract Law (n 14).

90 Cf Commission (EC) 'Completing the Internal Market' (White Paper) COM (85) 310 final, 14 June 1985, 22.
} 
new approach underlined a strategy that was catalysed by the famous Cassis de Dijon decision, in which the ECJ established the principle of mutual recognition. The Court overturned a German prohibition on the sale of alcoholic drinks which, according to German rules, should have had a higher percentage of alcohol. The ECJ's ruling in 1979 was that 'there is [...] no valid reason why, provided that they have been lawfully produced and marketed in one of the Member States, alcoholic beverages should not be introduced into any other Member State'. ${ }^{91}$ The immediate reason for relying on the negative integration approach was certainly the Commission's acknowledgement that the goal of completing the internal market by 1993 could not be achieved by relying exclusively on extension of the acquis, and that the volume of work still ahead had to be reduced. However, the 'new approach' has also forced national legislators to follow the diverse approaches to legal issues all over Europe. As such, the EC legislator's self-restriction, the four market freedoms, and negative integration have prepared the ground for regulatory competition among Member States' legal solutions in a non-discriminatory European sphere. The CFR could provide another catalyst to the regulatory competition scheme within Europe (and beyond).

\section{The Green Paper on the Review of the Consumer Acquis: limits to internal market thinking?}

Having supported the regulatory competition idea, however, it is important to examine divergent approaches concerning how minimum standards are and will be protected, so as to avoid a 'race to the bottom'. Most of the existing European consumer rules are based on the principle of 'minimum harmonisation'. This approach recognises the right of Member States to add stricter rules on top of European rules establishing a common platform for all Member States within the European Community, thus leaving room for regulatory competition even in harmonised areas of law while setting common (high) standards. However, in recent years the Commission has clearly signalled its attempt to redirect Community consumer policy towards a 'full' or maximum harmonisation approach. ${ }^{92}$ The Unfair Commercial Practices (UCP) directive was a first step in this direction, ${ }^{93}$ and the Commission was even more explicit in its Commu-

91 Case 120/78 Rewe-Zentral AG v Bundesmonopolverwaltung für Branntwein [1979] ECR 649.

92 For a deeper analysis, see eg G Howells, 'The Rise of European Consumer Law - Whither National Consumer Law?' (2006) Sydney Law Review 63; T Wilhelmsson, 'The Abuse of the "Confident Consumer" as a Justification for EC Consumer Law' (2004) Journal of Consumer Policy 317.

93 For a deeper analysis, see H-W Micklitz, 'Minimum/Maximum Harmonisation and the Internal Market Clause' in G Howells, H-W Micklitz and T Wilhelmsson (eds) European Fair Trading Law (Ashgate, Aldershot 2006) 83. 
nication on EU Consumer Policy Strategy 2007-2013: 'If legislative proposals are identified as the appropriate response, targeted full harmonisation of consumer protection rules at an appropriately high level will tend to be the Commission's approach'. ${ }^{94}$ This change in thinking is also apparent from the Commission's recent Green Paper on the Review of the Consumer Acquis. Although only a 'questionnaire', the Green Paper's argumentation opts primarily for a horizontal solution to future activity by the European legislator, and thus also for 'full harmonisation', pointing to certain 'issues' such as fragmentation and lack of confidence. It is obvious, therefore, that the Commission's focus on maximalist intervention has not changed.

The three main issues which the Green Paper identifies are new market developments, fragmentation of rules, and lack of confidence. ${ }^{95}$ Against the background of the ongoing debate about minimum versus maximum harmonisation, it is thus interesting to examine whether these issues represent viable arguments in favour of the Commission's way of thinking. Do market developments, the assumed fragmentation of rules, and lack of confidence really necessitate EC activity in the proposed manner?

In this respect, new market developments certainly give reason for constant attention by the EC legislator. Most directives were adopted in the 1980s or 1990s, and so require some alteration to meet the demands of today's rapidly evolving markets and new technological inventions. Hence, new market developments are a well-founded reason for reviewing the acquis. However, it is what is not stated in the Green Paper that reveals the market ideology followed by the Commission. It would have been more appropriate to cite comments on 'market developments' in terms of market growth via Community enlargement, for instance. Most of the directives were bargained among nine, ten, twelve or fifteen Member States, not 27 of them. Some further observations about the influence of the 'newcomers' would not have been out of place. Nevertheless, it remains a serious concern that a rapidly evolving market environment entails a regular quality review for existing legislation.

The second defined issue, fragmentation of rules, likewise gives good reason to review the acquis. The Green Paper distinguishes between two types of fragmentation: on the one hand, fragmentation caused by inconsistencies between directives; on the other, that caused by the minimum harmonisation approach, which allows Member States to adopt more stringent rules in their national laws. Nobody will deny the necessity of

94 Commission (EC) 'EU Consumer Policy Strategy 2007-2013' (Communication) COM (2007) 99 final, 13 March 2007, 7.

95 Cf Green Paper (n 85). 
reviewing the acquis so as to detect inconsistencies and other kinds of loopholes. However, while the second type of 'fragmentation' is presented virtually as a threat to the Community, minimum harmonisation only refers to the idea that the Community, in line with the subsidiarity principle, would set minimum standards and leave room for national deviations in specific matters. In fact, most directives are quite strict in terms of their demands, and 'fragmentation' is relatively easy to identify and, thus, to deal with. ${ }^{96}$

Even less convincing is the third identified issue, the 'lack of confidence' argument. Certainly, retailers have to reckon with some extra costs for cross-border sales. But are these really so difficult to determine that consumers will have to accept maximalist intervention by the Community, not allowing any room for possible higher protection in defined areas? The Eurobarometer results which the Commission uses to cement its argumentation are, at the least, unconvincing. For instance, the survey shows that 'as many as $45 \%$ of the consumers feel less confident in making purchases on the Internet from businesses located abroad', as further demonstrated by the fact that ' $44 \%$ of those who had Internet access at home made a domestic e-commerce purchase whereas only $12 \%$ made across-border e-commerce purchase'. ${ }^{97}$ However, is it not simply higher shipping costs, language barriers, and some anxiety about new technologies which lead to this phenomenon? It seems more appropriate to argue that the European consumer has profited highly from the Community's past harmonisation efforts, despite the minimum harmonisation approach. Nearly every consumer is aware, for example, of the minimum 2-year warranty scheme and certain other remedies available, even though he or she may not be aware of their European origin. But how many consumers really consider inconsistencies or slight divergences in cooling-off periods, for example?

To conclude, it seems inappropriate to head for a general maximum harmonisation scheme. It is too short-sighted to write minimum harmonisation off as minimalist patchwork, even though many older directives were not well drafted. Rather, it would be better to find improved quality management mechanisms for the legislative procedure. Here the CFR could help, offering clear definitions and principles that could prevent further fragmentation. Nevertheless, even when following a minimum harmonisation scheme, many issues will have to be formulated in a maximalist way so as to ensure the consistency of the acquis. But this does not mean that higher protection possibilities should be ruled out in any event.

96 On the question of the adoption or maintenance of more stringent national rules, see $\mathrm{P}$ Roth, 'Minimum harmonisation for the completion of the internal market? The example of consumer sales law' (2003) CML Rev 1107.

97 Green Paper (n 85) 7. 


\section{Some final remarks}

The European contract law project is said to be part of the Lisbon Strategy. ${ }^{98}$ At the Lisbon European Council in March 2000, the EU set itself the goal of making its economy the most competitive and dynamic knowledge-based economy in the world. At this point, however, the entire Lisbon Agenda appears to be heading towards outright failure of its original target date of 2010 (or even later), recalling the infamous 1992 deadline for completing the internal market. In this vein, the Commission has already changed its rhetoric: 'The single market is a means; it is not an end', and as such 'it will never be "finalised" or "complete". ${ }^{99}$ Does that not give cause to rethink the underlying values and refocus on European values, also with respect to contract laws? Europe has always been small in size, yet its richness stems from its fragmentation and diversity. Could this strength in difference not also boost Europe's innovativeness in the legal sphere?

Differences between national legal systems are the essential precondition for a learning process within the Community. In this regard, the negative harmonisation approach is an essential ingredient of the Community system's functioning. In addition, a sector-specific minimum harmonisation of laws and a process of recurrent review guarantee ever closer common standards in Europe. Minimum harmonisation does not mean that no room would remain for harmonisation to set welfare levels and protect standards that the Community agrees upon. The 'race to the bottom' argument seems very weak when confronted with today's achievements. Despite the minimum harmonisation approach, the Community has set minimum standards in all its areas of competence and, some would argue, even in certain areas beyond its competence (eg Tobacco Advertising). It is, of course, a reasonable concern that inconsistencies in the existing acquis be detected and loopholes leading to further fragmentation be closed. And one possible role of the CFR in this respect would be to serve as a quality-control instrument for drafting European legislation. Yet it would be counterproductive to close the door to opportunities arising from regulatory competition. Going even one step beyond this, the diversification of laws in a multispeed organisation would seem preferable to forcing a Community member to adopt lower standards than those it has chosen.

\footnotetext{
98 D Staudenmayer, for example, refers to the official strategy of the German government, which includes the CFR in a list of focal points on the agenda for achieving the Lisbon goals, in 'Weitere Schritte im Europäischen Vertragsrecht' (2005) Europäische Zeitschrift für Wirtschaftsrecht 103.

99 Commission (EC), 'A Single Market for Citizens - Interim Report to the 2007 Spring European Council' (Communication) COM (2007) 60 final, 21 February 2007, 3, 10.
} 
Due to the lack of more concrete criteria with respect to the internal market mandate, steps must be taken to involve stakeholders in legislative decision-making and increase its transparency. The conclusions from a public hearing on future single market policy in November 2006 point to welcome changes in the Commission's consultation procedures in general. ${ }^{100}$ In this respect, proposals concerning the way the Commission consults (for example, devising uniform consultation practices within the Commission, providing more feedback on the results, and ensuring better coordination among the Commission's DGs) are important and necessary in order to guarantee greater transparency, and thus legitimacy. ${ }^{101}$ Another issue is the degree of objectivity on the part of European institutions in the consultation process. The example of empirical studies shows that the Eurobarometer reports can be used to justify legislative activity. Yet relying on surveys requires a healthy dose of self-criticism and self-restraint. Why provide the general public with a questionnaire whose questions are drafted in a way that already suggests the next step? And why refer to individual survey results (supporting the need for EC activity) when the complete results are not yet published? For example, the Green Paper on the Review of the Consumer Acquis refers to a Flash Eurobarometer report on business attitudes which, however, was not accessible during the consultation period for the Green Paper. ${ }^{102}$

The European contract law project has given academia a chance to influence the Europeanisation of laws. However, it is questionable whether this opportunity to influence future developments has been used appropriately. The wide 'frame of reference' idea would also create space for setting up a common European education agenda. To quote Christian von Bar once again: 'What is on the agenda is the creation of a kind of model law with far-reaching consequences for a common education in law throughout Europe'. ${ }^{103}$ His words indicate precisely one of the real challenges we are facing today. Even with uniform laws, the lion's share of cases before courts will remain unclear and difficult. What is needed in such cases is, rather, well-educated lawyers who will have the skills to function in an increasingly integrated European and global environment. Therefore, legal education and training should include alternatives

100 For further information on future internal market policy, see $<$ http://ec.europa.eu/internal_market/strategy/index_en.htm/> accessed 30 May 2007.

101 Cf Single Market News no 44, January 2007, 4-6.

102 Green Paper (n 85) fn 15: 'Flash Eurobarometer 186 on business attitudes towards cross-border trade and consumer protection, conducted in October 2006. The survey will be published in its totality on the DG Health and Consumer Protection web page'. The fixed period for replies to the Commission's questions ended on 15 May 2007, but the survey was not available on the web page by that date.

$103 \mathrm{C}$ von Bar at the hearing of the European Parliament's Committee on Legal Affairs, 21 November 2006. 
to traditional basic law courses, in order to help the legal profession explore emerging fields of law and be able to react to changes in their field of expertise. ${ }^{104}$ Where, then, is the 'Study Group on Curriculum Design and Teaching Methods'?

It must be said that it is still too early to criticise the outcome of the European contract law project. Many excellent ideas have been presented in the course of modernising and re-integrating the European legal sphere. And whatever the final outcome will be, politicians will have benefited from the project and, at the same time, given a boost to European academia. European institutions will not only receive results legitimated by 'expert democracy', but they will also have finally made academics aware of changes within their profession. One could speak of a right step towards an 'ever closer union' of academics within Europe. When the Americans sent their first expedition to the Moon, Neil Armstrong's words were broadcast all over the world: 'That's one small step for a man, one giant leap for mankind.' And who cares if he was really standing on the Moon, or if the broadcast was being transmitted from a Hollywood studio. The real success were the innumerable inventions, patents and discoveries made on the way.

104 In this regard, see W van Gerven, 'Codifying European Private Law: Top Down and Bottom Up' in An Academic Green Paper (n 14) 405. 